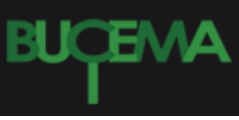

Bulletin du centre d'études médiévales

d'Auxerre | BUCEMA

Hors-série $n^{\circ} 2 \mid 2008$

Le Moyen Âge vu d'ailleurs

\title{
Os sinais da infâmia e o vestuário dos mouros em Portugal nos séculos XIV e XV
}

José Rivair Macedo

\section{(2) OpenEdition}

1 Journals

\section{Edição electrónica}

URL: https://journals.openedition.org/cem/9852

DOI: $10.4000 /$ cem. 9852

ISSN: 1954-3093

\section{Editora}

Centre d'études médiévales Saint-Germain d'Auxerre

\section{Refêrencia eletrónica}

José Rivair Macedo, " Os sinais da infâmia e o vestuário dos mouros em Portugal nos séculos XIV e XV », Bulletin du centre d'études médiévales d'Auxerre | BUCEMA [En ligne], Hors-série n 2 | 2008, mis en ligne le 24 janvier 2009, consulté le 02 mars 2023. URL : http://journals.openedition.org/cem/9852 ; DOI : https://doi.org/10.4000/cem.9852

Este documento foi criado de forma automática no dia 2 março 2023.

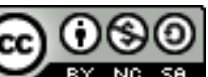

Creative Commons - Attribution - Pas d'Utilisation Commerciale - Partage dans les Mêmes Conditions 4.0 International - CC BY-NC-SA 4.0

https://creativecommons.org/licenses/by-nc-sa/4.0/ 


\section{Os sinais da infâmia e o vestuário dos mouros em Portugal nos séculos XIV e XV}

José Rivair Macedo

1 Nas Ordenações Afonsinas, de meados do século XV, os juristas a serviço de Afonso $\mathrm{V}$ fornecem alguns pormenores com respeito ao vestuário dos mouros do reino. Com base numa resolução tomada pelo governante anterior, D. Duarte, eles fixaram as normas atinentes ao tipo e forma do vestuário mouro, conferindo-lhes força de lei. Esta lei pouco conhecida, integrada à ampla e diversificada legislação aplicada à minoria islâmica, põe em evidência aspectos inusitados e intrigantes das relações inter-étnicas e inter-religiosas estabelecidas em solo peninsular.

2 No referido código legislativo, consta que os representantes dos mouros de Lisboa teriam apresentado a Afonso V uma carta de D. Duarte, datada de 22/11/1436, na qual este último informava ter recebido reclamação dos mouros lisboetas: o Alcaide Pequeno teria proibido que vestissem albernozes, ameaçando mandar prender os que fossem encontrados com o traje. Como se tratasse de vestimenta tradicional, permitida por cartas e privilégios reais anteriores, a medida constituía agravo aos direitos dos mouros, motivo pelo qual D. Duarte atendeu à petição que lhe fora encaminhada, confirmando a legalidade do vestuário em causa. Afonso $\mathrm{V}$, por sua vez, ratificou os termos da carta expedida pelo antecessor, transformando-a em lei e complementando-a com normas relativas às peças do vestuário mouro válidas para todas as populações muçulmanas do reino.

3 A legitimidade da lei fundava-se, pois, na expressão da vontade de D. Duarte que, por sua vez, fundava-se no reconhecimento das concessões de governantes anteriores. A primeira leitura do dispositivo legal não oferece maiores dificuldades de interpretação. Tudo leva a crer que ao inseri-lo no código legislativo Afonso $\mathrm{V}$ atendia o apelo dos mouros sob sua dependência, embora o prólogo do título não deixe claro as razões pelas quais a Comuna dos Mouros de Lisboa exibiu a carta de D. Duarte. Do modo como a questão é tratada, tem-se a impressão de que a reivindicação, considerada procedente, 
encontrasse legitimidade nos hábitos e tradições islâmicas - respeitados na legislação portuguesa. Contribui para tal a informação de que « os ditos albernozes era trajo usado, $e$ custumado em terra de mouros ${ }^{1}$ ». Além disso, fica a sugestão de que, ao pleitear o direito de manter seus costumes, os reclamantes desejassem distinguir-se dos cristãos, sendo a vestimenta um indicativo de sua identidade.

O exame mais atento do código afonsino e da legislação que o antecedeu sugere, porém, a existência de alguns pormenores pouco claros na presumida benevolência da lei. 0 problema que se coloca pode ser equacionado da seguinte maneira : teriam de fato os mouros pleiteado um direito, ou o traje era imposto a eles? De onde as indagações subsequentes : qual a forma de tratamento reservado às minorias étnico-religiosas em Portugal no tocante à sua indumentária $\mathrm{e}$; qual a relação entre os códigos de vestuário e as formas de sociabilidade na Idade Média em geral, e na Idade Média portuguesa em particular?

5 Antes de tratarmos destas questões, convém refletir a respeito da especificidade do objeto histórico aqui considerado, quer dizer, a vestimenta moura. Ao chamarmos a atenção para tal objeto esperamos contribuir para o aprofundamento das possibilidades de apreensão das articulações entre fenômenos sociais e culturais, uma vez que a roupa, mais do que o invólucro sob o qual os seres humanos escondem sua intimidade e individualidade, é o produto de uma elaboração coletiva e traz em si significados partilhados, expressos pelo gosto e pela moda, mas em determinados períodos históricos teve implicações jurídicas e sociais muito particulares.

6 Nos últimos tempos os Historiadores tem percebido a importância do vestuário para o estudo dos comportamentos coletivos e para a compreensão dos sistemas de valores do passado, dando-lhe alguma atenção. Os tecidos e outros produtos empregados na preparação das vestimentas e adornos corporais e os diferentes modos de cobrir o corpo exigem cuidado e atenção da parte do investigador. As práticas do vestuário levantam problemas de caráter antropológico, sociológico e psicológico. Os testemunhos concernentes a elas pertencem a um campo muito variado, dizendo respeito à arqueologia, à iconologia, aos textos literários e aos documentos oficiais, inclusive os códigos legislativos ${ }^{2}$.

7 Sem dúvida, a vestimenta é um signo de distinção. Entre as funções que desempenha nos diferentes conjuntos culturais, somam-se a de proteção contra os rigores da natureza, a busca de segurança física e moral, mas também o desejo pessoal de embelezar e diferenciar-se dos semelhantes, de ostentar certa posição ou certo status e, deste modo, impor-se perante o grupo. Ela passa a ser um signo, um elemento significante. Cumpre reconhecer a dimensão simbólica e ritual associada ao modo de se vestir, e que o grupo inscreve nos indivíduos que o compõe um discurso social, avaliando-o, enquadrando-o ou rejeitando-o. Há que se considerar, pois, o problema das atitudes e comportamentos em relação ao vestuário, e que ao se vestir as pessoas ficam expostas a um leque variado de considerações morais ${ }^{3}$.

$8 \mathrm{Na}$ sociedade medieval, altamente estratificada, os traços dos referidos comportamentos ficam bem delineados. A distinção imposta pela vestimenta pode ser observada nas estratégias de conservação social que permitiam a certos grupos o privilégio de portar tipos específicos de roupa e/ou acessórios pessoais, como os tecidos para o uso exclusivo da nobreza ${ }^{4}$, os hábitos e peças reservados ao meio eclesiástico, a vestimenta militar típica dos cavaleiros, os tecidos e peças proibidas aos burgueses, artesãos e camponeses. Christian de Mérindol dedicou atenção ao estudo desta 
hierarquização na França dos séculos XIV e XV, verificando a proveniência dos tecidos empregados na elaboração da indumentária aristocrática, os critérios técnicos ou econômicos invocados na escolha dos tecidos, os valores simbólicos das cores, enfim, um amplo espectro de fatores levado em conta na fabricação e no uso das roupas, verdadeiros signos de designação, classificação e distinção social ${ }^{5}$.

9 Na Idade Média a roupa exteriorizava a ordem estabelecida. Romper com tal imagem implicava em suscitar escândalo e em tornar-se estranho ao grupo que os indivíduos pertenciam, podendo os transgressores virem a ser reprovados ou condenados. Isto explica que os códigos de vestuário tenham ocupado lugar em leis promulgadas pelo menos desde o século XIII, e que se estenderam até o século XVIII, visando controlar o luxo e a ostentação indevida - as leis suntuárias ${ }^{6}$. 0 intento desta legislação era, ao mesmo tempo, uniformizar e desuniformizar os indivíduos, quer dizer, aproximar os iguais e distanciar os diferentes. Jesus Lalinde Abadia leu atentamente a legislação suntuária produzida na Espanha, constatando pelo menos quatro formas de discriminação através do vestuário : 1) o luxo estamental (determinação de certas vestimentas exclusivas da aristocracia); 2) o privilégio familiar; 3) o uniforme profissional - vestimentas próprias de alguns segmentos da sociedade, como os clérigos, os militares, os magistrados - ; 4) o distintivo infamante - destinado a marcar a separação de minorias étnico-religiosas, minorias sexuais, doentes e marginais ${ }^{7}$.

10 No presente estudo, interessa-nos em particular apenas o último ítem da classificação anterior, isto é, interessa-nos verificar em textos normativos os motivos pelos quais certos grupos eram discriminados por meio de distintivo infamante, dando atenção especial ao caso dos mouros e, em segundo lugar, ao dos judeus. Quanto ao marco geográfico, a análise residirá nas manifestações do problema em Portugal. Com efeito, existem vários registros nos códigos legislativos ou textos normativos concernentes aos sinais distintivos das duas minorias religiosas. A razão disto é que havia uma origem comum da atitude segregacionista, de cunho religioso. Convém portanto esclarecer esta origem para, depois, avaliar as vicissitudes e particularidades notadas em solo português.

11 Embora nosso intento seja compreender os valores associados ao vestuário mouro, somos forçados a considerar o problema dos sinais distintivos dos judeus porque ambos os grupos foram enquadrados numa mesma prescrição legal. Esta, por sua vez, insere-se numa tendência mais geral de discriminação por parte das autoridades medievais, num processo de constituição de minorias cuja raíz encontra-se nas decisões do IV Concílio de Latrão, de 1215, e cujos desdobramentos firmaram-se no decurso dos séculos XIII$\mathrm{XV}$, quando determinados grupos indesejáveis - judeus, leprosos, hereges, bruxas, prostitutas - foram progressivamente postos à margem da sociedade cristã ${ }^{8}$. Dentro deste amplo processo de exclusão o modo de se vestir era elemento significante, uma vez que governantes eclesiásticos e seculares tomaram a iniciativa de assinalar sua presença, valendo-se para tal de marcas infamantes ${ }^{9}$.

12 A distinção pelo vestuário era o sinal exterior de uma sanção moral dirigida a indivíduos tidos como perniciosos aos membros da sanior pars da sociedade. No caso em tela, tanto os judeus quanto os muçulmanos que viviam em território cristão eram considerados infames desde o nascimento, sofrendo por isso uma série de limitações de natureza jurídica que os rebaixavam perante a estima coletiva e afetavam sua publica fama, quer dizer, sua imagem social. A estes estava vedado o acesso a funções públicas ou a obtenção de honras, não lhes era reconhecido valor ao juramento e seu 
testemunho tinha pouca ou nenhuma credibilidade como meio de prova. Carregavam consigo o estigma da indignidade social, sendo portadores daquilo que os especialistas em história do direito qualificam de infamia facti ${ }^{10}$.

É a esta infâmia de origem que o cânon LXVIII do IV Concílio de Latrão parece fazer referência quando denuncia que em algumas províncias eclesiásticas judeus e sarracenos distinguiam-se dos cristãos porque levavam um vestido diferente, mas em outras, pelo contrário, reinava confusão tal que ninguém os distinguia, resultando por vezes, e por equívoco, uniões indevidas entre pessoas dos diferentes credos. Para evitar aquelas uniões reprováveis os prelados instituíram então que em todas as províncias cristãs, em todos lugares e momentos, judeus e sarracenos portassem um traje especial, diferente do vestuário cristão. A intervenção visava, desta maneira, impedir a promiscuidade que eventuais relações sexuais com pessoas infames poderia representar à pureza da comunidade cristã. No mesmo artigo, os prelados também denunciaram a pompa da vestimenta judaica nos dias da semana santa, motivo de opróbrio e ofensa à Cristo, proibindo-os de sair de suas residências naqueles dias ${ }^{11}$.

Dois aspectos merecem ser sublinhados. $O$ primeiro diz respeito à efetiva competência da Igreja em legislar sobre judeus e mouros, uma vez que aqueles não eram batizados e, assim sendo, escapavam da jurisdição eclesiástica. Do ponto de vista legal, parece injustificável que tenham sido objeto de prescrições similares ${ }^{12}$. Todavia, as autoridades eclesiásticas não apenas incorporaram a decisão em seu corpo legislativo, inserindo-a no Corpus Iuris Canonici (livro V, título VI), mas atribuíram a execução da norma ao braço secular, ordenando aos príncipes que castigassem os transgressores mediante penas apropriadas ${ }^{13}$. Em segundo lugar, judeus e sarracenos foram igualados e enquadrados numa mesma prescrição, embora ocupassem posição distinta no seio da comunidade cristã. Do modo como está redigido, o cânon parece ter visado prioritariamente os judeus, tanto que é ao opróbrio provocado pela ostentação de sua roupa que o texto faz referência, até porque, como se sabe, eram estes mais ricos que os mouros e ocupavam lugar de maior destaque na Cristandade. Por conseguinte, a aplicação do cânon LXVIII veio a ser feita de modo diferente para os dois grupos, tendo na prática significados distintos, como teremos oportunidade de demonstrar a seguir.

ém disso, o referido artigo canônico determinava a obrigatoriedade do uso de trajes especiais, mas era omisso quanto ao aspecto que deveriam ter. Para os judeus, o sinal infamante variou em detalhes e cores, consistindo no porte de uma roda de feltro amarelo costurada nas vestes que lhes cobria o peito ou o ombro (roelle, rouelle, rotela), de uma estrela amarela, ou então no uso de um chapéu cônico. A fixação da norma deveu-se à insistência das determinações tomadas em sucessivas assembléias de prelados, entre as quais destacam-se o Concílio de Narbonne em 1227, de Arles em 1234, Béziers em 1246, Albi em 1254, Arles em 1260, Nimes em 1284, Avignon em 1326 e 1337. A transposição para a legislação secular remonta a 1232, quando André II, rei da Hungria, mandou escrever uma lei na qual obrigava ismaelitas e judeus ao uso de signos distintivos. Décadas depois, no reino da França, os sinais no vestuário judaico foram instituídos na parte suntuária dos Établissements de São Luís, em lei promulgada pelo seu irmão, Alphonse de Poitiers e, em 1283, por Filipe III, o Ousado ${ }^{14}$.

Quanto à Península Ibérica, a transposição da decisão conciliar provocou algumas resistências e hesitações. Em Aragão, já em 22/12/1228 Jaime I, o Conquistador, obrigou os judeus a usar sinal distintivo em público, mas em Castela Fernando III mostrou alguma relutância em fazer o mesmo, uma vez que parte da comunidade judaica 
ameaçava abandonar o reino e migrar para terras sob domínio islâmico, tal a indignação que sentiram. O rei pleiteou a Honório III a suspensão da medida e foi atendido pelo papa, conforme carta datada de 13/04/1219, do Arquivo da Igreja Metropolitana de Toledo ${ }^{15}$. Em Portugal, os governantes do século XIII não parecem ter se esforçado o suficiente para a implementação da norma canônica, motivo pelo qual, nas queixas apresentadas pelo clero a D. Dinis em 1289, este era acusado, entre outros benefícios à comunidade israelita, de não aplicar o que o Concílio Geral tinha previsto com respeito ao sinal distintivo ${ }^{16}$.

17 A pressão clerical era recorrente nos decretos papais e nas decisões emanadas dos concílios peninsulares. Em 1239 Gregório IX, à pedido dos prelados de Córdova e Baeza, mandou que o bispo de Córdova obrigasse os judeus ao uso dos sinais ${ }^{17}$. A mesma decisão aparece nas atas do Concílio de Valladolid, em 1228, nas do Concílio de Zamora em $1313^{18}$, e nas do Sínodo de Alonso de Fonseca celebrado em Ávila em 10/09/1481, onde aos judeus era prescrito o uso público de sinais vermelhos, aos mouros, capuzes amarelos com luas azuis e às mouras, luas de pano azul nos mantos, para que « fossem conhecidos e se evitasse erros e pecados ${ }^{19}$ ".

18 Na legislação secular ibérica, o preceito veio a ser incorporado nas decisões e atos dos governantes mas sofreu matizes e adaptações, o que nos sugere terem os executores da norma percebido melhor as especificidades de cada uma das comunidades votadas à discriminação. Isto pode ser observado nos textos produzidos na corte de Alfonso X, o Sábio. Os legistas a serviço do rei incorporaram às Siete Partidas a prescrição do canon LXVIII, mas dirigiram-na apenas aos judeus, os quais deviam trazer algum sinal sobre as cabeças para se fazerem conhecidos, sob pena do pagamento de dez maravedis ou, na falta destes, dez açoites em público ${ }^{20}$. O referido sinal parece ter sido o chapéu cônico, com o qual eram retratados na iconografia alfonsina ${ }^{21}$. Além disso, nas decisões relativas ao tipo de vestimenta, alimentação e gastos permitidos ou vedados às diversas categorias sociais do reino tomadas nas cortes de Valladolid em 1258 os judeus ficavam proibidos de usar vestimentas luxuosas, ostentatórias ${ }^{22}$.

É interessante reparar que, no caso em pauta, à orientação clerical do uso do sinal distintivo somam-se proibições características da legislação suntuária castelhana. Já no que respeita aos mouros, Alfonso $X$ limitou-se a definir que tipo de vestimenta deveriam trazer, vedando-lhes o uso de trajes luxuosos - permitidos apenas aos cristãos pertencentes à nobreza. Não determinou a obrigatoriedade do uso de sinais distintivos externos costurados na roupa, obrigando-os entretanto a se fazerem conhecer por marcas distintivas em seu aspecto físico. É o que se pode depreender da lei suntuária expedida em Sevilha no dia 27/02/1256, na qual consta que os mouros deveriam distinguir-se dos cristãos pelo tipo de corte de cabelos e pelo uso de barba longa ${ }^{23}$.

É bem provável que a notada distinção no modo de encarar mouros e judeus se devesse às diferentes formas de interação daquelas minorias étnico-religiosas com a comunidade cristã. Tem-se a impressão de que os judeus, presentes há mais tempo na Cristandade, continuavam a ser marcados e distinguidos por sinais artificiais como há muito tempo ${ }^{24}$. No que tange aos mouros, incorporados ao domínio cristão há menos tempo, parece que a separação estava condicionada ao quanto fossem obrigados a manter-se presos a seus costumes ancestrais (así como manda su ley). Deveriam ser facilmente reconhecidos como mouros, o que se obtinha pelo aspecto visual da vestimenta islâmica, pelo corte do cabelo ou pelo tamanho da barba, como se pode notar também na decisão tomada por Jaime II de Aragão nas cortes de Lérida em $1300{ }^{25}$. 
21 Convém sublinhar as similaridades das disposições legais castelhanas e aragonesas concernentes ao sinal distintivo dos mouros. Com efeito, incluem-se na vasta gama de possibilidades encontradas pelos membros das sociedades tradicionais de todo o mundo - inclusive na Idade Média européia - para classificar e, noutras vezes, hierarquizar os indivíduos através de convenções expressas nos modos de arranjar e conservar o cabelo e o sistema capilar. Os arranjos do cabelo e da barba serviam como um dos indicativos da situação das pessoas no interior do grupo, demarcando posições sociais e diferenças religiosas, identificando diferenças etárias e assinalando as mudanças de status por ocasião de rituais de passagem ${ }^{26}$.

Naquelas sociedades, a cabeleira masculina simbolizava a força. Cabelos soltos, compridos e intactos, exprimiam virilidade, valentia ou poder, mas cortados ou raspados significavam, pelo contrário, uma oferenda religiosa ou lembrava submissão e renúncia. Porém, não parece ser esta a conotação a ser dada às decisões legislativas ibéricas, de que os mouros os trouxessem cortados ao redor e sem topetes, uma vez que nas mesmas decisões determinava-se que usassem barba. É mais provável que o intuito das leis fosse mantê-los presos aos códigos de sociabilidade do mundo islâmico, onde o corte parcial dos cabelos e o cultivo de barbas longas estava em conformidade com seus valores e práticas religiosas ${ }^{27}$.

Os ecos da legislação alfonsina podem ser observados em Portugal, cuja organização legislativa constituía, no dizer de Joaquim Lavajo, um «decalque das legislações eclesiásticas e hispânicas naquilo que dizia respeito ao local de habitação, o modus vivendi e o vestuário de judeus e mouros ${ }^{28}$ ". Com efeito, há concordância entre os especialistas quanto ao peso do direito canônico - sobretudo as Decretales extra Decretum Gratiani vagantes, elaboradas por Raimundo de Peñafort a pedido de Gregório IX -, do direito romano - o Código de Justiniano seguido da Glosa de Acúrsio e dos comentários de Bartolo de Sassoferrato - e do direito castelhano - nomeadamente a tradução dos tratados de Jácome das Leis, do Fuero Real e das Siete Partidas - nas decisões régias, vindo tais normas a servir como fontes subsidiárias no ordenamento jurídico do reino português ${ }^{29}$.

24 A influência do preceito canônico pode ser notada, por exemplo, nas reiteradas decisões e resoluções régias com respeito ao traje dos judeus. Parece ter sido Afonso IV quem pela primeira vez os obrigou a se fazerem distinguir mediante o uso de sinal amarelo no chapéu. D. Pedro I mandou que o referido sinal fosse trazido bem visível, no peito, e D. João I, para fazê-los acatar a medida sem alternativas ou expedientes que pudessem ocultar a marca infamante definiu a forma e o local em que seria usada: deviam trazer no peito, acima do estômago, uma estrela vermelha hexagonal tão grande como o seu selo redondo, e bem à vista ${ }^{30}$. Quando os governantes dispensavam alguns membros da comunidade judaica a exibi-la provocavam vivos protestos por parte dos representantes dos concelhos municipais ${ }^{31}$. Estas idas e vindas nas decisões governamentais sugerem que a medida despertava resistências e nem sempre era cumprida, e que quando o era, nem sempre se aplicava a todo o conjunto da comunidade hebraica ${ }^{32}$.

25 Tal qual sucedera com o sinal dos judeus, foi Afonso IV quem, no princípio do século XIV, obrigou os mouros a se fazerem reconhecer pelos cristãos. Devemos a informação a uma fonte tardia. Consta na sétima parte da Monarqvia Lusitana, redigida por Frei Rafael de Jesus em 1683, a decisão do monarca em separar de modo eficaz as comunidades judaica e moura da dos cristãos, a fim de moralizar os costumes. Segundo 
o cronista, rezava a tradição que aqueles vivessem apartados, em bairros divididos, e cercados, proibidos de se comunicar com os moradores das povoações em que habitavam, sendo conhecidos "pellos trajes de suas naçoens ». Contudo, a passagem do tempo amenizou a aversão e relaxou a norma. Judeus e mouros alteraram sua indumentária, "ate que a semelhança desmentio a differença, e a uniformidade do traje facilitou o dano, que no moral e no politico começou a sentir ». O rei corrigiu a corrupção dos costumes, "mandando cõ rigurosas penas, que nenhu mouro vestisse sem deviza, que o publiccasse, e nenhu judeu sem sinal que o distinguisse : o destes amarelo no chapeo, o daquelles branco no turbante, ou no barrete ». Informa também que, noutro decreto, proibiu aos portugueses os topetes, aos judeus as gadelhas e aos mouros o cabelo, mandando que o dos mouros fosse cortado à navalha, e o dos judeus, à tesoura ${ }^{33}$.

Esta última informação não parece dizer respeito a uma medida legal destinada a distinguir os três grupos religiosos da sociedade portuguesa. Nada aqui faz lembrar os cabelos cortados em redor ou repartidos e o uso obrigatório de barba para os mouros, vigentes na legislação dos reinos espanhóis desde o século XIII. Talvez seja apenas uma prova da austeridade do monarca, uma vez que Frei Rafael de Jesus acrescenta que o topete dos portugueses era um enfeite que lhes dava a impressão de efeminados, verdadeira afronta a um povo belicoso ${ }^{34}$. Quanto a menção ao corte dos cabelos de judeus e mouros, também contém apenas significado moral, não tendo constituído medida efetiva, até porque não reaparece em qualquer lei posterior ${ }^{35}$. Assim como aos portugueses era conveniente trazer os cabelos longos, aos grupos minoritários, considerados inimigos, parecia bom que os trouxessem curtos e, se possível, raspados. 0 tamanho da cabeleira é aqui considerado sinal de virilidade, pois « nos proprios cabellos tinha Sansão as forças ; e para se mostrar que as não tem, se cortão aos forçados ${ }^{36}$ ".

27 A este propósito, não será preciso insistir que, nas sociedades tradicionais, o corte dos cabelos constituía signo de infâmia recorrentemente utilizado para denunciar certos tipos de infração de natureza sexual. No caso, Frei Rafael de Jesus pode ter pretendido denunciar o perigo de eventuais contatos físicos entre homens judeus ou mouros com mulheres cristãs, facilitados pela indistinção da vestimenta. Segundo Edmond Leach, em geral cabelo curto ou cabeça parcialmente raspada indicavam sexualidade restringida, e a cabeça toda raspada, impotência sexual ${ }^{37}$. Além disso, acreditava-se que nos cabelos residiam certas virtudes ou certos poderes do possuidor. Na tradição hebraica, quando longos, eles expressavam força física, força espiritual e vitalidade, traço apontado no mito de Sansão, mas curtos eram objeto de mofa e zombaria ${ }^{38}$.

Quanto às prescrições atinentes ao vestuário, a descrição deixada pelo cronista merece maior atenção. Estão em conformidade com o sentido moralizador da ação daquele governante, inclusive com as medidas destinadas a sanear os costumes e controlar os gastos, fixadas por ocasião das cortes de Santarém em 1340. Nos vinte e sete artigos que perfazem o documento aprovado naquela assembléia, cinco dizem respeito aos limites de gastos com alimentação e dezoito ao tipo de vestuário reservado às diferentes categorias do reino: ricos-homens, filhos d'algo, cavaleiros, escudeiros, peões, cidadãos ${ }^{39}$. Entretanto, nada consta na Pragmática de 1340 a respeito do vestuário judeu ou mouro, de onde se pode inferir que as questões relativas às duas minorias religiosas foram tratadas em separado por Afonso IV, e que a regulamentação de seu vestuário tinha finalidade específica.

Na passagem citada da Monarqvia Lusitana Rafael de Jesus informa que a lei tinha o propósito de manter separados aqueles que poderiam representar ameaça aos cristãos, 
sendo o traje signo visível da diferença. Convém reparar, uma vez mais, a distinção estabelecida com relação aos dois grupos aos quais parecia necessário segregar : os mouros deveriam ser identificados por divisa costurada em suas vestes habituais (turbante ou barrete), os judeus, pelo sinal amarelo no chapéu. Além de trazer um sinal exterior, cumpria aos primeiros manterem-se distinguidos por suas próprias vestimentas de origem. Outro testemunho alusivo a esta decisão, desta vez de um provável contemporâneo do governante, indica-nos melhor as particularidades então impostas. Na estrofe de um poema atribuído ao trovador Afonso Giraldes, consta que Afonso IV :

$$
\begin{aligned}
& \text { " fez bem aos criados seus } \\
& \text { e grão honra aos privados } \\
& \text { e fez a todos os judeus } \\
& \text { trazer sinaes divisados } \\
& \text { e os mouros almexias } \\
& \text { que os pudessem conhecer }{ }^{40} \text { " }
\end{aligned}
$$

Nos versos, os sinais divisados dos judeus contrastam com a almexia dos mouros. Ora, a consulta aos dicionários etimológicos de língua portuguesa coloca-nos diante de significados não muito precisos com respeito ao vocábulo empregado para designar o sinal distintivo em pauta. A definição aceita por vários estudiosos ${ }^{41}$ reproduz idéia equivocada expressa por Joaquim de Santa Rosa Viterbo ao final do século XVIII, para quem almexia designava "certo sinal que el-rei D. Afonso IV mandou que os mouros de Portugal trouxessem sobre os vestidos quando não usassem o seu próprio traje ", tendo extraído a informação do Dicionario portuguez e latino, do erudito Rafael Bluteau. Este, por sua vez, baseava-se no suposto poema de Afonso Giraldes. Mário Fiúza, editor moderno do dicionário de Viterbo, contestou o valor científico do verbete porque sua acepção provinha, em última instância, de um poema apócrifo de data incerta, acrescentando que o vocábulo indicava uma espécie de túnica curta usada pela classe mais humilde dos mouros da Península, mas passou a ser o vestuário obrigatório da população islâmica, que, deste modo, "mostrava a sua condição de "mouros", não se podendo confundir com os cristãos ${ }^{42}$ ".

31 Segundo pensamos, a observação de Mário Fiúza está correta, mas não invalida o testemunho do poema de Afonso Giraldes. De fato, ampliando a pesquisa da raiz etimológica do vocábulo em pauta para a língua castelhana, temos que almejia era uma espécie de túnica usada pelos hispanoárabes, mencionada pela primeira vez em documento datado de 919 , e de uso corrente no século XIII ${ }^{43}$. Com efeito, era o traje típico usado pelos mouros retratados nas miniaturas das Cantigas de Santa Maria, talvez o melhor testemunho visual dos mouros peninsulares. É vestida com uma luxuosa almexia azul que a Virgem Maria aparece caracterizada no códice marial florentino ${ }^{44}$. Segundo José Guerrero Lovillo, que estudou em detalhes os traços iconográficos das cantigas do manuscrito do Escorial, a palavra almexia designava uma túnica ampla, um manto de tamanho variável usado pelos árabes e que era também identificado pelo nome de alquicel ${ }^{45}$.

Portanto, no início a almexia era apenas uma peça do vestuário tradicional dos mouros, mas em solo peninsular, e em virtude das leis promulgadas com o fim de diferenciá-los dos cristãos, passou a ser vestimenta obrigatória. O problema, neste caso, dizia respeito ao risco de, em virtude do contato inter-étnico, aqueles abandonarem suas vestes típicas e adotarem o vestuário cristão. A mesma obrigatoriedade valia para outras peças de sua indumentária, como a aljuba, o albernoz e o turbante, todos eles mencionados 
aqui ou acolá nas decisões das autoridades quando prescreviam normas atinentes ao seu modo de vestir.

Entre os diplomas expedidos por D. Pedro I está uma carta mandada escrever em 18/02/1359, na qual o rei informa ter sido solicitada pela Comuna dos mouros de Moura a dispensa do uso das aljubas e albernozes enquanto aqueles trabalhassem na lavoura, pois eram pobres e isto lhes constituía agravo. Além disso, pediam que lhes fosse dispensado o uso de aljubas com mangas largas, "de dous palmos de ancho». O governante deu parecer favorável às solicitações, liberando-os da obrigação de portar aqueles trajes durante suas ocupações, mas manteve a norma do uso em todos os momentos em que se encontrassem fora da mouraria, inclusive no percurso de ida e volta ao local de trabalho. Permitiu que o tamanho da manga das aljubas fosse menor que os dois palmos, e que a roupa fosse confeccionada com qualquer tecido, mas não deixou de especificar quais sinais deveriam ser nelas inscritos a fim de que se fizessem conhecer à primeira vista ${ }^{46}$.

As informações do documento revelam-nos a condição social dos mouros, gente pobre, acostumada ao trabalho do campo. A solicitação que encaminharam ao rei nos permite supor viverem numa situação contraditória, resultante das características de sua inserção na sociedade portuguesa. Como poderiam realizar trabalho braçal que exigia esforço físico e provocava desgaste com roupas mal adaptadas para esse fim? Isto porque, no período anterior à Reconquista, aquelas eram peças caras, usadas em geral pelas pessoas mais ricas da comunidade islâmica. De fato, a aljuba, era uma espécie de túnica que descia até os joelhos, tendo meias mangas muito largas e sendo justa até a cintura ${ }^{47}$. Quanto ao albernoz, palavra oriunda da língua bérbere, burnus, designava um manto de linho à semelhança de jibão acompanhado de um capuz o qual se colocava por baixo da aljuba, feito em geral com tecido de algodão e, em casos excepcionais, com lã ${ }^{48}$.

Em estudos sobre a vestimenta mudejar nos testemunhos iconográficos castelhanos da segunda metade do século XIII, como o Libro del Aljedrez, dados y tablas de Alfonso X, certos estudiosos tem colocado em evidência o quanto o traje mudejar adaptou-se às modas imperantes na sociedade castelhana, influência tanto maior nas camadas menos aquinhoadas ${ }^{49}$, embora o mesmo possa ser dito em relação às incorporações mouriscas à indumentária cristã ${ }^{50}$. Parece-nos que, do lado mouro, a adaptação era o resultado da convivência, mas também do desprestígio que aqueles trajes de origem poderiam representar. Seja qual for o motivo, o fato é que as autoridades estavam atentas e esforçavam-se para marcar o distanciamento que a mudança da indumentária poderia diminuir. Esta separação tornou-se mais nítida com a resolução de D. Pedro I uma vez que, à semelhança dos judeus, os mouros de Moura e, talvez por extensão, os mouros de todo o reino, passavam a ter que ostentar no peito uma marca distintiva. A decisão era explícita a este respeito, pois mandava que «tenham quartos diante nos peitos... por serem conhecidos por mouros ", algo possivelmente inédito até então.

Outras providências foram tomadas pelo mesmo monarca visando a efetiva separação entre os membros das três religiões do reino. Nas cortes de Elvas de 1361, renovou a medida adotada por seu pai anos antes, confinando judeus e mouros a bairros apartados do restante da população ${ }^{51}$, e, algum tempo depois, atendendo a solicitação dos moradores de Lisboa que reclamavam da presença incômoda de judeus e mouros nas partes frequentadas por cristãos - com risco físico para as mulheres -, baixou uma lei em 19/09/1366 proibindo que qualquer cristã pudesse entrar sozinha, de noite ou de dia, no arrabalde onde morassem os mouros, salvo por caminho prescrito e 
devidamente acompanhadas por homens da comunidade, na ausência destes por um ou dois homens do rei e, na ausência destes, por homens encarregados pela vigilância da cidade. Tanto a mulher que não observasse a determinação quanto o mouro ou moura, judeu ou judia que a recebesse em sua casa, deveriam ser submetidos à pena de morte ${ }^{52}$.

Desta maneira, ao fim do século XIV, os códigos de vestuário das duas minorias encontravam-se enraizados na legislação portuguesa. Disto nos dá conta a petição do concelho da cidade de Lisboa a D. João I, que motivou a carta régia de 3/12/1390, na qual o fundador da dinastia de Avis lembra as resoluções tomadas por seu pai (D. Fernando) e por seu avô (D. Pedro) visando impedir a « maldade » que poderia resultar da relação entre homens " imíjgos da fe catolica » com "molheres christãas », mandando a seguir que se fizessem cumprir a lei. Ao cair da noite, judeus e mouros deveriam ser confinados em seus arrabaldes. Além disso, determinou que os judeus portassem sinãaes vermelhos de çerta medida por serem bem divisados. E os mouros alJubas $»{ }^{53}$.

As Ordenações Afonsinas

Voltemos às Ordenações Afonsinas. Antes porém de reexaminarmos os dados que comparecem no título CIII do Livro II, cumpre esclarecer as circunstâncias da composição deste código legislativo, a fim de compreender melhor o contexto em que foi preparado e o real alcance de seus dispositivos. Não resta dúvida de que as normas ali contidas ocupem uma posição destacada na história do direito português, e que representem o resultado mais acabado da evolução legislativa que se vinha formando desde Afonso III, em meados do século XIII. Sua importância é ainda maior considerando que serviu de base para coletâneas posteriores - as Ordenações Manuelinas e as Ordenações Filipinas -, que a atualizaram.

Entretanto, a preparação do código legal não está diretamente ligada ao governante cujo nome costuma ser identificado. Foi ainda no reinado de D. João I que, mediante as queixas formuladas nas cortes quanto ao estado de confusão das leis, este encarregou o corregedor João Mendes a proceder a elaboração de uma coletânea sistemática de leis e de outras fontes jurídicas a fim de realizar a desejada reforma. Morto o monarca, a tarefa prosseguiu sob o curto reinado de D. Duarte, tendo sido a compilação entregue aos cuidados do conselheiro Rui Fernandes, que a concluiu apenas em 1446, durante a regência do Infante D. Pedro - que governava em nome de Afonso V. O texto foi entregue a uma comissão revisora composta por Lopo Vasques, corregedor de Lisboa, e pelos desembargadores Luís Martins e Fernão Rodrigues, que o examinaram e alteraram algumas partes. A publicação ocorreu ao final de 1447 ou princípio de 1448, ainda sob a regência de D. Pedro, embora tenham sido incluídas algumas leis posteriores, até 1454 . Sua entrada em vigor veio a ser lenta e a divulgação, restrita, uma vez que haviam muito poucas cópias em uso. $O$ certo é que a vigência não foi longa, pois no princípio do século XVI veio a ser reformada e substituída pelas Ordenações Manuelinas.

Primeira composição oficial do direito português, as Ordenações Afonsinas foram elaboradas a partir das fontes legais existentes, incorporando resoluções régias, concordatas celebradas com o clero, preceitos consuetudinários e foraleiros, articulados com disposições extraídas das Siete Partidas, do direito romano e canônico quer diretamente, quer através das obras de glosadores e comentadores. Quanto à estrutura orgânica, compõe-se de cinco livros : o primeiro dedicado aos regimentos de diversos cargos públicos; o segundo, aos bens e privilégios do clero, aos direitos régios, 
à jurisdição e prerrogativas da nobreza, e à legislação especial para judeus e mouros ; o terceiro, às normas de processo civil ; o quarto, ao direito civil substantivo ; o quinto, ao direito e processo penal ${ }^{54}$.

41 Cada um dos livros compreende certo número de títulos, com rúbricas indicativas de seu objeto, e cada título aparece subdividido em parágrafos. Quanto à técnica legislativa, quase todo o primeiro livro segue o estilo decretório, isto é, apresenta a matéria como se esta fosse legislada pela primeira vez. Nos demais, adotou-se o estilo compilatório, que consistia na transcrição integral da fonte ou fontes existentes a respeito da matéria tratada, seguidas de comentário, confirmação ou alteração do regime jurídico em vigor ${ }^{55}$. É o estilo compilatório que comparece na redação do título CIII do livro II porque, para legislar sobre a vestimenta moura, a fonte utilizada é uma resolução contida na carta de D. Duarte em resposta à petição dos mouros de Lisboa. A partir do conteúdo e do parecer ali contidos é que a equipe de juristas declarou os termos em que a lei viria a ser formulada.

Os problemas começam a aparecer quando a fonte invocada na enunciação da norma legal é submetida a uma apreciação crítica. Para começar, diga-se que a carta supostamente firmada por D. Duarte em 22/11/1436 não se encontra arrolada no conjunto de documentos publicados da chancelaria daquele monarca ${ }^{56}$. Também não consta no prólogo da lei os motivos pelos quais o referido documento teria sido exibido pelos mouros de Lisboa a Afonso V, mas a impressão é que a iniciativa teria partido deles, impressão reforçada pelas informações aparentemente favoráveis a eles que o documento contém.

43 Entretanto, estes dados não estão em conformidade com as normas legais atinentes aos trajes impostos aos membros da comunidade islâmica portuguesa desde o século XIV, como tivemos oportunidade de mostrar nas páginas anteriores. Por conseguinte, parece estranho que o Alcaide de Lisboa os ameaçasse por usarem albernozes, já que este era uma das vestes distintivas de sua condição de mouros. Mais estranho ainda que D. Duarte tenha atendido ao pedido da comuna dos mouros como se lhes reconhecesse um direito, uma vez que se tratava de um dever ${ }^{57}$. É preferível pensar que, ao tratar da matéria, nem D. Duarte nem a equipe de jurisconsultos à serviço do Infante D. Pedro e de Afonso $\mathrm{V}$ pretendessem proteger o direito dos mouros, mas sim garantir a sua presença perto dos cristãos, sem que por isso os dois grupos partilhassem um mesmo espaço.

Examinando as medidas tomadas por D. João I e seus sucessores na passagem do século XIV para o XV o que se pode verificar são indícios de desgaste das condições mínimas de convívio com os mudejares, condições estas resultantes das vicissitudes da Reconquista ${ }^{58}$. Os governantes da dinastia de Avis viveram numa época de intolerância crescente dos cristãos em face das minorias étnico-religiosas, como provam as sucessivas perseguições movidas contra os judeus que viviam na Espanha e as reiteradas mobilizações de pregadores com vistas à conversão de judeus e mouros ${ }^{59}$.

Em Castela, a rainha Dona Catarina, regente durante a menoridade de D. João II, ordenou em 02/01/1412 que todos os judeus e mouros do reino vivessem em comunidades situadas fora dos limites das cidades ou vilas, separados por uma cerca com apenas uma porta, sob pena de confisco dos bens; que não comercializassem qualquer mercadoria de comer ou beber com cristãos ; que não comessem ou bebessem junto com os cristãos, não lhes prestasse nenhum tipo de serviço nem se valessem de trabalhadores cristãos; que mouros e mouras não se vestissem como os cristãos e que 
os homens não cortassem a barba com navalha ou tesoura. Em 09/11/1408 prescreveu aos mouros a obrigatoriedade do uso sobre as vestes de um capuz de pano amarelo e da inscrição de uma grande lua cor turquesa costurada no ombro direito, sob pena da perda das roupas e cinquenta açoites em público ${ }^{60}$.

Não se verifica em Portugal medidas tão truculentas como as de Castela. De qualquer modo, desde pelo menos a segunda metade do século XIV tanto os pareceres dos monarcas quanto as petições que lhes foram apresentadas por procuradores das comunidades nas cortes do reino atestam a progressiva intolerância no trato com os adeptos do Talmud e do Alcorão. Assim, atendendo ao pedido dos moradores de Santarém, em 2/10/1385 D. João I proibiu que judeus e mouros ocupassem qualquer cargo naquela vila, e determinou que judeus e mouros encontrados fora de suas respectivas judiarias ou mourarias depois do toque de recolher pagassem pesada multa. Nas cortes de Évora de 1436 reclamava-se da proximidade entre o cemitério mouro e o adro do Mosteiro de São domingos. No mesmo ano, os mouros de Elvas representaram a D. Duarte reclamação segundo a qual os rendeiros da almotaçaria entravam na mouraria, interferindo nos hábitos ali mantidos. Décadas mais tarde, por carta régia dada em Estremoz no dia 20/08/1466, Afonso V atendeu os moradores de Montemor o Novo, reclamavam terem os judeus e mouros descumprido a norma de viverem apartados, exigindo provisão da justiça " por avergomça e infamya » que a proximidade e " conversaçom» poderiam provocar. Dois anos mais tarde, em 1468, deferiu o pedido formulado nas cortes de Santarém, para que se cumprisse a lei que os obrigava ao uso de sinal distintivo ${ }^{61}$.

Reparando melhor as prescrições legais extraídas da carta de D. Duarte concernente ao traje dos mouros, temos que o governante permite-lhes que usem seus albernozes e suas aljubas, mas acrescenta ao hábito vestimentário o uso de capuzes ou balandraus, "visto como o trajo, que ora trazem, he assaz devisado dos dos christãaos ». Mas não foram estas as prescrições incorporadas às Ordenações Afonsinas. Tendo-as em referência, a equipe de juristas aprofundou-as, chegando a uma formulação um pouco diferente. Neste caso, determinava-se o uso de aljubas com aljubetes cujas mangas fossem muito largas; de albernozes e escapulários; de balandraus ou capuzes com escapulários no lado detrás, acrescentando : " e o que nom trouxer cada hua das ditas roupas, perca a roupa que trouxer, e seja preso ataa nossa mercee; e trazendo as ditas roupas, se nom forem taaes, como devem, segundo suso he declarado, percão-nas e jaçam na cadea quinze dias ${ }^{62}$ ».

Assim, ao contrário do tom conciliador da resolução de D. Duarte, que lhe serviu de fonte, a lei formulada no título CIII prescreve uma norma jurídica e especifica a respectiva pena aos infratores. Embora as aljubas, albernozes e balandraus fossem trajes costumeiros dos mouros, suficientes para distingui-los, os legisladores obrigaram-nos a portar as vestes longas costuradas e fechadas na frente, o que além de lhes provocar incômodo no momento em que realizavam suas atividades de trabalho ía contra os seus costumes. Disto nos dá conta uma carta datada de 11/12/1454, na qual Afonso $\mathrm{V}$ atendeu o pedido dos mouros de Lisboa, pois :

" custumarom sempre trazerem capas abertas per diante e capellos de tras que he trajo de mouro assy como sempre trouuerom e ainda trazem todollos outros mouros foros de nossos regnos, e que mantendo elles assy seu custume do dito trajo que os dessebargadores da nossa cassa do ciuell, que esta em esta çidade lhe foi mandado da nossa parte que nom trouuessem mais as ditas capas abertas soomente todas cosseitas e çarradas per diante, em o que dizem que lhe foi feito agrauo por seerem as ditas capas per a dita guissa muito pejadas para com ellas poderem seruir 
e trabalhar e ainda seer lhe posta semelhante defessa que nom he a nenhuus outros mouros forros de nossos regnos, pedindonos que lho mandassemos correger e tornar a seu custume, e visto per nos seu requerimento e querendolhe fazer graça e mercee, teemos por bem e queremos e mandamos que daquy em diante possam trazer as capas todas abertas per diante com seus capellos de capuz segundo soyam de custumar sem embarguo de qualquer mandado ou defessa que lhe per os sobreditos nossos dessenbargadores ou quaees quer outras perssoas em nosso nome fosse ou seja posta ${ }^{63}$. " relativas ao vestuário geraram reações na comunidade muçulmana de Lisboa, diretamente afetada. Além disso, as normas instituídas na comuna de mouros de Lisboa eram importantes pois aquela estava mais próxima do poder central, sofria maiores pressões da parte de funcionários à serviço da monarquia e servia de modelo para outras comunidades islâmicas. Seu funcionamento era visto como um paradigma para as demais e as normas ali aplicadas costumavam ser estendidas a todas as comunas $\mathrm{e}$ mourarias do reino.

No que respeita às Ordenações Afonsinas, as prescrições atinentes ao vestuário são melhor compreendidas quando inseridas no conjunto mais vasto de medidas visando impedir legalmente o contato inter-religioso e inter-étnico ${ }^{64}$. Convém lembrar que os títulos anteriores e posteriores ao CIII transformavam em lei a resolução tomada por D. João I, de que todos os mouros forros do reino vivessem em mourarias separadas, sem comunicação ou contato com os cristãos, reiteravam as disposições vigentes desde o século XIV relativas ao horário em que as portas das mourarias deveriam ser fechadas, e a proibição de que mouros entrassem nas residências de mulheres cristãs. Consta também no livro $\mathrm{V}$ um título específico dedicado ao caso de judeus ou mouros que se vestiam como cristãos para ter com mulheres cristãs ${ }^{65}$. Sabemos que, nestes casos, o rigor das penas efetivava-se na prática. Em carta régia datada de 12/05/1473, Afonso $\mathrm{V}$ determinou que Jufez Cigarró, da mouraria de Évora, fosse condenado à pena corporal e tivesse os bens confiscados porque foi provado que dormira com uma moça cristã chamada Guiomar, moradora da mesma cidade ${ }^{66}$.

510 certo é que, na segunda metade do século $\mathrm{XV}$, os sinais distintivos exteriores à própria roupa dos mouros foram sendo incorporados à legislação corrente. Nas cortes de Santarém de 1451 foi-lhes proibido o uso de roupas de seda e em 1472, nas cortes de Coimbra, previa-se a pena de vinte açoites para os mouros, brancos ou negros, que tirassem os sinais costurados na vestimenta. Alguns anos depois, em 1481, D. João II decidiu, nas cortes de Évora, que deviam usar capuzes abertos com uma lua vermelha costurada no ombro ${ }^{67}$. Na opinião de Maria Filomena Lopes de Barros, a obrigatoriedade dos sinais aplicava-se apenas aos mouros cativos, sobretudo aqueles recentemente introduzidos no reino, e não aos mouros forros ${ }^{68}$. Temos alguma dúvida, pois em decisões posteriores ao século XV continuam a aparecer menções ao uso da lua vermelha nos albernozes de todos os mouros ${ }^{6}$.

52 A lua crescente, como se sabe, era o símbolo com o qual os cristãos identificavam os muçulmanos. Quanto ao vermelho, estava associado no sistema de cores do ocidente medieval com a falsidade, traição e desonra. Segundo Michel Pastoureau, a simbólica do vermelho quase sempre relaciona-se com o sangue e o fogo. Por isso, havia um vermelho visto de modo positivo e um vermelho visto de modo negativo. $O$ vermelho do sangue era o que dava a vida, purificava e santificava, mas o vermelho do fogo indicava impureza, violência e pecado, estando ligado aos tabus do sangue herdados da Bíblia, à

Bulletin du centre d'études médiévales d'Auxerre | BUCEMA, Hors-série nº 2 | 2008 
carne impura, aos crimes de sangue e aos homens revoltados contra deus ou contra os outros homens. Era cor obrigatória empregada na discriminação dos portadores de certas enfermidades contagiosas (como a lepra), ou então de cristãos que desempenhavam funções desonrosas (como os carrascos e prostitutas) ${ }^{70}$.

Assim, o exame da legislação da monarquia portuguesa nos permite pensar que o uso da vestimenta dos mouros constituía um signo de infâmia. Embora diferente da discriminação visual imposta aos judeus, o porte obrigatório de aljubas e albernozes era também um sinal infamante, pelo qual os governantes regulamentaram as condições da convivência social entre cristãos e muçulmanos, confinando os adeptos do islamismo aos espaços marginais das cidades e assinalando em seu aspecto visual as marcas indicativas de seu estatuto de minoria.

\section{NOTAS}

1. Ordenações Afonsinas. Reprodução fac-símile da edição feita na Real Imprensa da Universidade de Coimbra, no ano de 1792, Lisboa, Fundação Calouste Gulbenkian, s. d., livro II, título CIII, p. 537.

2. M. MADOU, Le costume civil, Turnhout, 1986 (Typologie des sources du Moyen Âge occidental, 47), esp. p. 15-17 e 48-55.

3. O. Blanc, « Historiographie du vêtement : un bilan », in Le vêtement : histoire, archéologie et symbolique vestimentaire au Moyen Âge, Paris, 1989, p. 25-26. Para as conotações sociais negativas atribuídas a certos tipos de vestimenta, ver M. PASTOUREAU, o tecido do diabo : uma história das riscas e dos tecidos listrados, trad., Lisboa, 1992.

4. A vestimenta era signo de distinção e status nos romances de cavalaria, como demonstrou J. LE GOFF, « Observações sobre os códigos de vestuário e alimentar em Erec et Enide ", in J. LE GOFF, O maravilhoso e o quotidiano no Ocidente Medieval, Lisboa, 1985, p. 93-110. Ver também P. LE RIDER, «À propos des coutumes... De Giraut de Barri au Conte du Graal et à Fergus ", Le Moyen Âge, 107/2 (2001), p. 253-282.

5. C. de MÉRINDOL, « Signes de hiérarchie sociale à la fin du Moyen Âge d'après le vêtement. Méthode et recherche ", in Le vêtement : histoire..., op. cit., p. 181-222. 6. Na França, a primeira lei suntuária foi assinada por Filipe, o Belo, em 1294. Ver P. LACROIX, Recueil curieux de pièces originales, rares ou inédites sur le costume et les revolutions de la mode en France, Paris, s. d., p. 7-16.

7. J. LALINDE ABADIA, « La indumentaria como simbolo de la discriminacion juridicosocial », Anuario de Historia del Derecho Español, 53 (1983), p. 583-599.

8. H. ZAREMSKA, « Marginais », in J. LE GOFF y J.-C. SCHMITT, dir., Dicionário temático do Ocidente Medieval, trad., São Paulo, 2002, t. 2, p. 121-235 ; J. RICHARDS, Sexo, desvio e danação : as minorias na Idade Média, Rio de Janeiro, 1992.

9. A obra de Ulysse Robert (Les signes d'infamie au Moyen Âge:juifs, sarrasins, hérétiques, lépreux, cagots et filles publiques, Paris, 1891), continua a ser referência obrigatória a respeito do problema, embora existam ali poucas indicações relativas aos sinais 
infamantes dos muçulmanos. A Inquisição teve papel importante na determinação de trajes especiais aos hereges, leprosos e cagots, e aos integrantes de minorias religiosas. 10. As restrições acarretadas pela infâmia eram significativas na Idade Média, quando o valor dos laços pessoais e dos vínculos de confiança permaneceram sempre fundamentais na sociedade. A respeito da definição e classificação da infamia facti, cf. A. M. DE ALMEIDA COSTA, 0 registo criminal : história, direito comparado, análise políticocriminal do instituto, Coimbra, 1985, p. 40, para quem : «traduzia-se a infamia facti num juizo de desvalor moral, dirigido pela colectividade contra a pessoa de um de seus membros. Ou seja, consistia num juízo desfavorável sobre a personalidade de um indivíduo, podendo, conforme a mundividência da época, assentar numa multiplicidade de fundamentos : v.g., quer na condição de nascimento, quer na prática de actos ou na adopção de formas de vida contrários ao código ético-social vigente ». Alem disso, ver A. MARCET, «Les infames du Roussillon (XIII ${ }^{\mathrm{e}}-\mathrm{XVIII}^{\mathrm{e}}$ siècle) ", in Minorités et marginaux en France Méridionale et dans la péninsule Ibérique, Actes du Colloque de Pau, 27-29 mai 1984, Paris, 1986, p. 432, para quem a infamia facti teria recaído também sobre os integrantes de « un groupe ethnique marginalisé, voir rejeté en bloc, ce qui leur confère en quelque sorte une infamie d'origine».

11. C.-J. HEFELE, Histoire des conciles d'après les documents originaux, trad. H. LECLERCQ, Paris, 1913, t. 5, deuxième partie, p. 1386-1387.

12. J. de Assunção Ferreira (Estatuto jurídico dos judeus e mouros na Idade Média Portuguesa, Salamanca, 1994, p. 50) considera injustificável a aplicação das normas da Igreja às minorias religiosas.

13. Neste ponto, não estamos completamente de acordo com Antonio Garcia y Garcia [ "Derecho canónico y vida cotidiana », Revista Portuguesa de História, 25 (1988), p. 205] para quem a Igreja não tinha e nem pretendia ter poder direto sobre judeus e maometanos, e que sua influência nesta matéria dependeu em cada momento do grau de autoridade fática efetivamente exercida sobre as autoridades temporais.

14. U. ROBERT, Les signes d'infamie..., op. cit., p. 14-22.

15. J. AMADOR DE LOS RIOS, Historia social, politica y religiosa de los judios de España y Portugal, Madrid, 1960, p. 893-894.

16. Valemo-nos da transcrição da Primeira concordata entre D. Dinis e o Clero, publicada por F. DE ALMEIDA, História da Igreja em Portugal, Nova edição preparada e dirigida por D. PERES, Lisboa, 1971, t. 4, apêndice IX, p. 68.

17. I. SANZ SANCHO, « Notas sobre las relaciones de los judíos y conversos con la sociedad cordobesa en la baja Edad Media », Diálogo filosófico-religioso entre Cristianismo, Judaísmo e Islamismo durante la Edad Media en la Península Ibérica. Mediaevalia, 5-6 (1994), p. 137.

18. J. de Assunção FERREIRA, Estatuto jurídico dos judeus e mouros na Idade Média Portuguesa, p. 74 y 85 .

19. A. GARCiA y GARCIA, dir., Synodicon Hispanum, Madrid, 1993, t. 6 (Avila y Segovia), p. 204.

20. Las Siete Partidas del Sabio rey don Alonso el nono, nuevamente glosadas por el licenciado Gregorio Lopez, feito em Salamanca em 1565, partida 7, titulo 24, lei 11. Para a versão modernizada do texto, ver Las Siete Partidas, selección, prologo y notas de F. LÓPEZ ESTRADA Y M. T. LóPEZ GARCíA-BERDOY, Madrid, 1992, p. 418-419.

21. Ver, por exemplo, as miniaturas do Libro de Ajedrez, dados y tablas de Alfonso el Sabio, estudio por P. GARCIA MORENO, Madrid, 1977, fig. 14 y 16. 
22. Citado por J. SEMPERE y GuARIÑos, Historia del luxo y de las leyes suntuarias de España, reprodução facsimilar da edição original de 1788, Madrid, Lope de Vega, 1973, p. 91. Decisão similar foi tomada nas cortes de Jeres em 1268, e nas cortes de Palência em 1313. Cf. J. LALINDE ABADIA, « La indumentaria como simbolo... », op. cit., p. 597-598. 23. J. SEMPERE Y GUARIÑOS, Historia del luxo..., ibid., p. 91. A mesma disposição encontra-se nas decisões das cortes de Valladolid, de 1258 : « que anden cercenados al rededor, ó el cabelo parado sin copete, é que trayan barbas largas, como manda su ley... », J. SEMPERE Y GuARIÑos, Historia del luxo..., ibid., p. 95.

24. Sabe-se que na Espanha muçulmana, sobretudo nos período de dominação dos almorávidas e almoâdas, os moçárabes e judeus eram obrigados a se distinguir dos crentes em Alá, e que o mesmo se aplicava aos judeus de Granada no princípio do século XIV. Cf. J. LALINDE ABADIA, « La indumentaria como simbolo... », op. cit., p. 596-597 ;

U. ROBERT, Les signes d'infamie..., op. cit., p. 62.

25. Costitutions et altres dretz de Catalunya supérfluos, livro I, cap. XII, p. 10. Citado por F. FERNANDES Y FERNANDES, Estado social y político de los mudejares de Castilla, considerados en si mismos y respecto de la civilizacion española, Madrid, 1866, anexo no LVI, p. 369.

26. Ver A. VAN GENNEP, Les rites de passage. Étude systématique des rites, Paris, 1909, p. 238 ; M. ElIADE, Naissances mystiques. Essai sur quelques types d'initiation, Paris, 1959, p. 51.

27. Conforme Y. DESLANDRES e M. DE FonTANES, « História das modas do toucado ", in J. POMIER, dir., História dos costumes, Lisboa, 1998, t. 2 (As técnicas do corpo), p. 219 : « Os homens das sociedades islâmicas aceitaram o costume de rapar a cabeça de um modo mais ou menos parcial sem, contudo, deixar de usar barbas e bigodes. Certos grupos islamizados dos Irão, como os nómades Bakhtyari, apenas rapam a parte anterior do crânio a fim de não sujar a pedra sobre a qual se prosternam para orar... E em praticamente todo o mundo islâmico a barba branca dos homens de idade é o sinal de sua sabedoria e experiência. »

28. J. CHORÃo LAVAJO, "Islão e cristianismo : entre a tolerância e a Guerra Santa ", in

A. M. C. M. Jorge e A. M. S. A. RodrigueS, coord., História Religiosa de Portugal, Lisboa, 2000, t. 1 , p. 107.

29. G. BRAGA DA CRUZ, O direito subsidiário na história do direito português, Coimbra, 1975, esp. p. 181-182, 194-195 e 207.

30. Ordenações Afonsinas, livro II, título LXXXVI, p. 499-500. Para a evolução das disposições concernentes ao distintivo judaico em Portugal, ver J. LEITE DE VASCONCELOS, Etnografia portuguesa, Lisboa, 1958, t. 4, p. 88-90.

31. Em 1371 D. Fernando concedeu dispensa do uso do sinal a dois judeus de Lisboa, motivando protestos nas cortes de Lisboa, reunidas naquele mesmo ano. Reclamações deste tipo repetem-se nas cortes reunidas sob o governo de Afonso V e D. João II, sobretudo nas de Santarém em 1468 e nas de Évora, em 1481. Cf. H. DA GAMA BARRos, " Judeus e mouros em Portugal em tempos passados (apontamentos históricoetnográficos) », Revista Lusitana, 34 (1936), p. 176-177 e 192-193. Ver ainda M. J. PIMENTA FERRo, Os judeus em Portugal no século XIV, Lisboa, 1970, p. 60-62.

32. Para M. J. Ferro Tavares (Os judeus em Portugal no século XV, Lisboa, t. 1, p. 404) todas estas medidas legislativas revelam-se infrutíferas, apesar do rigor da pena. A respeito da vestimenta judaica e da obrigatoriedade do uso dos sinais, diz a mesma autora, no ensaio «O difícil diálogo entre judaísmo e cristianismo », in A. M. C. M. JorGE e A. M. S. A. RodRigues, coord., História Religiosa de Portugal..., op. cit., t. 1, p. 68 : « apenas sabemos que eles deviam vestir-se como o povo, ou seja, sem adornos de luxo e vestes 
caras. No entanto, temos de concluir que tal não era praticado pelos judeus mais ricos, a crermos nos protestos dos procuradores dos concelhos, apresentados nas Cortes. 0 mesmo se passava com o próprio distintivo, que os judeus estavam dispensados de usar em viagem, para evitar os assaltos contra as suas pessoas e fazendas. »

33. Monarqvia Lusitana, Parte Setima, Contem a vida de el rey Dom Affonso o Quarto por excellencia o Bravo, composta pello cronista mor Frey Raphael de Iesus, reprodução facsimilar, Lisboa, 1985, p. 243.

34. Outros testemunhos confirmam a existência de um decreto de Afonso IV que dizia respeito à disposição do cabelo dos cristãos. A Ley dos topetes foi instituída nas cortes de Santarém de 1340, tendo sido inserida no Livro de leis e posturas, transcrição de M. T. CAMPOS RODRIGUES, Lisboa, 1971, fl. 144, p. 395, nos seguintes termos : « Outrosy teemos por bem que nenhuu christãao de nosso senhorio de qualquer estado E condiçom que seiam nom andem espartidos $E$ aquel que acharem andar espartido pague dez libras por cada uez que o asy acharem E seia preso ata que ffaçam o Topete... »

35. Neste ponto, afastamo-nos parcialmente de M. VIEGAS GUERREIRO, « Mouro », in J. SERRÃo, dir., Dicionário de história de Portugal, Lisboa, s. d., t. 4, p. 352, e de J. Chorão Lavajo ("Islão e cristianismo... », op. cit., p. 112) para os quais Afonso IV teria obrigado os mouros ao corte do cabelo à navalha, como se se tratasse de um sinal distintivo. Possivelmente os estudiosos tenham concedido valor excessivo à informação contida na crônica do beneditino, sem examinar a passagem com mais atenção.

36. Monarqvia Lusitana, Parte Setima..., op. cit., p. 244.

37. E. LEACH, « Cabelo mágico », in R. DA MATTA, Leach (Coleção Grandes cientistas sociais), São Paulo, 1983, p. 143-145 e 152.

38. « Hair », in The Jewish Encyclopedia, New York, 1907, t. 6, p. 157-158 ; E. BEURLIER, "Cheveux », in Dictionnaire de la Bible, Paris, 1912, t. II-C, p. 684-691.

39. ANTT, Maço 1, Suplemento das cortes, doc no 4. A transcrição integral do documento encontra-se em A. H. de OliveIRA MARQUES, "A Pragmática de 1340 », in A. H. de OlIVEIRA MARQUES, Ensaios de história medieval portuguesa, Lisboa, 1980, p. 109-119.

40. O poema encontra-se em T. BRAGA, Antologia Portugueza, Porto, 1876, p. 35-36. Sobre a historicidade da obra de Afonso Giraldes, ver M. MARTINS, « Frei Alvaro Pais e o poeta Afonso Geraldes », in M. MARTINS, Estudos de cultura medieval, $2^{\mathrm{e}}$ ed., Lisboa, 1980, p. 70-76.

41. J. P. MACHADO, Grande dicionário da língua portuguesa, Algés, 1989, t. 1, p. 345 : « Almexia - do ár. Al-mehaxia : arruela, divisa ou sinal que Afonso IV, de Portugal, mandou que os mouros trouxessem na roupa, quando não usassem o trajo oriental »; M. L. Mártires Martins (Subsídios para o estudo dos judeus e dos mouros nos reinados de D. João I e D. Duarte, Lisboa, 1961, p. 150), confunde-se ainda mais ao afirmar, apoiandose em Viterbo, que « determinou D. Afonso IV que os mouros quando não vestissem o seu trajo característico deviam usar um sinal, uma lua de pano vermelho cosida sobre o ombro - a almexia ».

42. J. DE SANTA ROSA VITERBO, Elucidário das palavras, termos e frases que em Portugal antigamente se usaram e que hoje regularmente se ignoram, $1^{\text {a }}$ ed. 1798, edição crítica M. FIÚZA, Porto, s. d., t. 1, p. 398.

43. J. CoRominas, Dicionario crítico etimológico de la lengua castelhana, Madrid, 1974, t. 1, p. 147.

44. A. GARCIA CUADRADO, Las cantigas : el códice de Florencia, Murcia, 1993, p. 252. 
45. J. GUERRERO LOVILLO, Las cantigas : estudio arqueológico de sus miniaturas, Madrid, 1949, p. 185. Determinar a natureza da imagem do vestuário da Virgem em solo peninsular constitui um aspecto particular do processo de sincretismo cultural entre cristãos e muçulmanos no Ocidente, o qual não temos condições de esclarecer neste momento. Convém assinalar, todavia, que a referida imagem parece ter sido introduzida na iconografia ibérica cristã no século XIII.

46. Chancelaria de D. Pedro I (1357-1367), ed. preparada por A. H. DE OLIVEIRA MARQUES, Lisboa, 1984, doc. $\mathrm{n}^{\mathrm{0}} 360$.

47. J. DE SANTA ROSA VITERBO, Elucidário das palavras..., op. cit., t. 1, p. 384.

48. J. COROMINAS, Dicionario crítico..., op. cit., t. 1 , p. 88 ; R. ARIÉ, « Le costume des musulmans de Castille au XIII ${ }^{\mathrm{e}}$ siècle d'après les miniatures du Libro del ajedrez », in Mélanges de la Casa de Velázquez, 2 (1966), p. 62-63.

49. J. C. De Miguel RodRiguez, Los mudejares de la corona de Castilla, Madrid, t. 4, 1987, no 8 , p. 36.

50. Conforme nos informa C. Bernis Madrazo (Indumentaria medieval española, Madrid, 1956, p. 21) os castelhanos chamavam de aljuba uma túnica exterior usada por cima de sayas e gonelas, e por baixo de mantos e sobretudos até pelo menos o século XV.

51. H. DA GAMA BARROS, « Judeus e mouros... », op. cit., 34 (1936), p. 168.

52. Chancelaria de D. Pedro I, doc. $\mathrm{n}^{\circ} 1131$.

53. Arquivo Histórico da Câmara Municipal de Lisboa, Livro dos Pregos (codice $\mathrm{n}^{\circ} 45$ ), doc. n² 245, fl. 185. Transcrito por M. L. MÁrTIRES MARTINS, Subsídios para o estudo..., op. cit., anexo no 1, p. 217-218.

54. N. E. GOMES DA SILVA, História do direito português, Lisboa, 1969, p. 294-295.

55. M. J. De Almeida Costa, História do Direito Português, Coimbra, 1996, p. 274-277 ; M. J. DE ALMEIDA COSTA, Temas de História do direito, Coimbra, 1970, p. 62-66.

56. Chancelarias portuguesas - D. Duarte (1435-1438), organização e revisão geral por J. J. AlVES DIAS, Lisboa, 1998, 2 vol. Cabe aqui a advertencia de M. J. DE ALMEIDA CostA, Temas de História..., ibid., p. 66, para quem : « Constituem as Ordenações Afonsinas uma importante fonte para o conhecimento do direito anterior à sua publicação. Devem, todavia, ser utilizadas com o máximo de cuidado. É que nem sempre os textos foram reproduzidos de uma forma exacta, e, além disso, frequentemente os compiladores atribuíram a um monarca leis pertencentes a outro.»

57. Sem a devida contextualização, os termos da carta de D. Duarte podem induzir ao erro de apreciação da questão, como veio a ocorrer com Joaquim Chorão Lavajo (« Islão e cristianismo... », op. cit., p. 112) ao afirmar que : « não foi pacificamente aceite pelos cristãos, ao longo dos tempos, a indumentária dos muçulmanos. Os primeiros não toleravam, por exemplo, que usassem albernozes, e os segundos apelavam para os reis, reclamando o respeito pelas leis que salvaguardavam os seus usos e costumes e invocando que essa era a indumentária por eles usada em terras de mouros... » 58. Convém lembrar as palavras de M. F. LOPES DE BARROS, A comuna muçulmana de Lisboa : séculos XIV e XV, Lisboa, 1998, p. 19, segundo a qual : « Numa perspectiva diacrónica, os séculos XIV e XV indiciam um propósito de interferência da sociedade circundante sobre a organização das comunas mudéjares, pese à protecção declarada dos soberanos (sobretudo face às pretensões do clero), em paralelo com uma afirmação cada vez mais clara da maioria cristã, nos seus aspectos religioso, económico e social. A esta tendência não deve ser alheia uma aculturação crescente dessas mesmas comunas, aliada a uma retracção populacional das mesmas. » 
59. Sobre o problema da orientação eclesiástica castelhana e portuguesa com respeito ao batismo das minorias religiosas, ver J. ANTUNES, « Acerca da liberdade de religião na Idade Média : mouros e judeus perante um problema teológico-canônico », Revista de História das Idéias, 11 (1989), p. 62-84. Quanto às pressões para a conversão em Castela nas primeiras décadas do século XV, ver J. TORRES FONTES, « Moros, judios y conversos en la regencia de Don Fernando de Antequera », Cuadernos de Historia de España, 31-32 (1960), p. 82-85 ; I. SANZ SANCHO, « Notas sobre las relaciones... », op. cit., p. 131-136. 60. F. FERNANDES Y FERNANDES, Estado social..., op. cit., aneXos no LXXVI-LXXVII, p. 397-405.

61. H. DA GAMA BARROS, « Judeus e mouros... », op. cit., 34 (1936), p. 171-172, 176 e 211 ; 35 (1937), p. 192 e 216.

62. Ordenações Afonsinas, livro II, título CIII, p. 539.

63. ANTT, Chancellaria de D. Affonso V, livro 19, fl. 119v, transcrito por SOUZA VITERBo, «Ocorrências da vida mourisca », Archivo Historico Portuguez, 5 (1907), p. 84.

64. J. LEITE DE VASCONCELOS, Etnografia..., op. cit., t. 4, p. 331-333.

65. Ordenações Afonsinas, livro II, títulos CII, CIV, CV, p. 536-537 e 540-541 ; livro V, título XXVI, p. 96. Tais determinações remontam aos reinados de Afonso IV e D. Pedro I. Ver acima, notas 31 e 50-51.

66. H. DA GAMA BARROS, « Judeus e mouros... », op. cit., 35 (1937), p. 195-196.

67. H. DA GAMA BARROS, « Judeus e mouros... », op. cit., 34 (1936), p. 174 e 178 ; 35 (1937), p. 232. A distinção entre mouros brancos e negros devia-se à entrada em Portugal de escravos africanos, que na nomenclatura quatrocentista eram nomeados « mouros negros ». Ver A. C. DE C. M. SAUNDERS, História social dos escravos e libertos negros em Portugal (1441-1555), Lisboa, 1994, p. 13.

68. M. F. LOPES DE BARROS, A comuna..., op. cit., p. 140.

69. ANTT, Chancelaria de D. Manuel, livro 6, fl. 110v, transcrito por SOUZA VITERBO, «Ocorrências... », op. cit., p. 84.

70. M. PASTOUREAU, « Les couleurs médiévales : systèmes de valeurs et modes de sensibilité », in M. PASTOUREAU, Figures et couleurs. Études sur la symbolique et la sensibilité médiévales, Paris, 1986, p. 39-41; Ver ainda do mesmo autor o Dicionário das cores do nosso tempo, Lisboa, 1997.

\section{ÍNDICE}

Índice geográfico: Portugal

Mots-clés: Maures

\section{AUTOR}

JOSÉ RIVAIR MACEDO

Universidade Federal do Rio Grande do Sul 